American Journal of Applied Sciences 2 (9): 1315-1320, 2005

ISSN 1546-9239

(C) 2005 Science Publications

\title{
Comparative Analysis of Economic Policies in Korea and Malaysia after the Financial Crisis
}

\author{
Seok Yoon \\ Research Fellow, Korea National Assembly Library, 1 Yoido dong \\ Young deung po-ku, Seoul, 150-703, Korea
}

\begin{abstract}
The Asian Economic Crisis of 1997 escalated from Southeast Asia and landed in Northeast Asia. However, in the process of recovery from the crisis, two countries took the opposite approaches. The Korean Government adopted the plans from the IMF and received a rescue fund, but the Malaysian Government adopted the independent recovery plans. With strong fundamentals, a generally liberal and continued integration approach into the global market-Mahathir's limited capital controls notwithstanding-Malaysia would probably see its economic recovery in relative good health again, even if with the 2-digit growth of the last decade. Therefore, this Malaysian Government's approach shows the importance of the self-supporting economy when confronting with the WTO's economic system and financial crisis. This study aims to evaluate after the financial crisis of the Korean economy with a special emphasis on the Korean government's structural reform efforts under the IMF program and Malaysia's capital control policy, it points out many issues of the Korean economy.
\end{abstract}

Key words: Economic policy, financial crisis, capital control policy

\section{INTRODUCTION}

The 1997 Asian economic crisis started in Southeast Asian countries and swept over Northeast ones only after several months. While each country had a different economic structure and as a result, took different economic measures to cope with the crisis, one of the common factors it experienced was the depreciation of the currency and the depressed stock market. The instability in the financial sector affected the object economy; international trade was disturbed, the unemployment rate increased, interest rate hiked and investments plunged. Measures had to be taken to improve the overall economic system as depression became uncontrollably serious and prolonged.

Korea also experienced the so-called 'IMF Coldwaves' from the end of November 1997. Following a harsh stock market collapse, interest rate increased to about 30\%. Abrupt depreciation of Korean Won (W) drained the foreign exchange reserves of Korea and accelerated the economic crisis. Korea's Sovereign credit rating was degraded to non-investment, a sharp fall by six grades ${ }^{[1]}$. At last, the Korean government asked the IMF for relief financing and took massive structural reshuffle as the IMF requested ${ }^{[2]}$.

On the other hand, Malaysia experienced the financial crisis but the toil Malaysians experienced and countermeasures for the crisis were quite different from those of Korea. Like other South Asian countries, Malaysia also experienced stagnant economic growth, unstable prices, shrinking local spending and exports and a decline in capital and public investments. Unlike Korea, however, Malaysia reacted to such financial crisis by adopting a strong capital control policy and the fixed exchange rate system in order to stabilize exchange rates and boost financial sectors. The country recorded 5.8\% and $8.5 \%$ economic growth rates in 1999 and in 2000 respectively and its economy became stabilized as the current account balance turned to red ${ }^{[3,4]}$. Call rate also sharply decreased from $7.75 \%$ in September 1989 to 3.19\% in August 1999 and price index held steady after the capital control policy was implemented.

Korea and Malaysia showed similarities in the process of financial crisis but clear differences in counter economic measures to overcome the crisis. This study will focus on comparing the background which made two countries implement different economic policies and the results of such policies. It will also make an effort to find out the lessons that the economic policies of Malaysia could imply for the restructuring of the Korean financial industry and corporations.

\section{COUNTERMEASURES FOR THE FINANCIAL CRISIS}

The Financial Crisis of South East Asian countries, which were initiated in Thailand in June 1997, was treated with two different countermeasures. First, countries like Korea and Thailand received IMF rescue financing and accepted a so-called global standard, with which capital and financial markets are open. Second, countries like Malaysia refused to liberalize and open its capital and financial markets and took capital control measures as they believed that the abrupt movement of short-term money caused the crisis.

Corresponding Author: Seok Yoon, Research Fellow, Korea National Assembly Library, 1 Yoido dong, Young deung po-ku, Seoul, 150-703, Korea, Tel: +82-2-788-4353, Fax: +82-788-4430 
Table 1: Countermeasures of countries and IMF supports IMF Support \& Policy Intervention

\begin{tabular}{llll} 
& & Support & Refusal to Support \\
\hline Accepting & Positive & Korea & Singapore \\
IMF & Thailand & Malaysia \\
& Passive & Indonesia & \\
\hline
\end{tabular}

Table 2: Status of foreign exchange of three countries (as end of 1997)

\begin{tabular}{lccr}
\hline & Malaysia & Korea & \multicolumn{1}{c}{ Thailand } \\
\hline $\begin{array}{l}\text { Balance of Budget } \\
\text { (to GDP \%) }\end{array}$ & 2.4 & -0.2 & -1.0 \\
$\begin{array}{l}\text { Foreign Exchange } \\
\begin{array}{l}\text { Holding (US\$100 million) } \\
\text { The number of Month }\end{array}\end{array}$ & 217.0 & 89.0 & 90.0 \\
$\begin{array}{l}\text { for Import meeting } \\
\text { Foreign Debt }\end{array}$ & 3.4 & 0.70 & 1.8 \\
$\begin{array}{l}\text { (US\$100 million) } \\
\text { Corporate Sector }\end{array}$ & 447.0 & 1,544 & 934.0 \\
Short-term Debts & 40.5 & 88.3 & 74.0 \\
$\begin{array}{l}\text { Foreign Debts'GDP }(\%) \\
\text { Foreign Debts / Export (\%) }\end{array}$ & 28.5 & 44.3 & 37.3 \\
Foreign Currency Holding & 62.7 & 58.7 & 92.2 \\
/ Short-term Debts $(\%)$ & 170.0 & 111.4 & 164.7 \\
\hline
\end{tabular}

Note: 1) Foreign exchange holding of Korea (US\$8. 9 billion) was usable at hand. 2) The foreign exchange holding of Korea in 1997 was somewhat different from US $\$ 158$ billion announced by the Korean government. But the figure in the same source was used for the comparison.

Source: ABN-AMRO, 1999. Asian Market Quarterly

Table 3: Asian countries foreign exchange holdings and short-term debt ratios

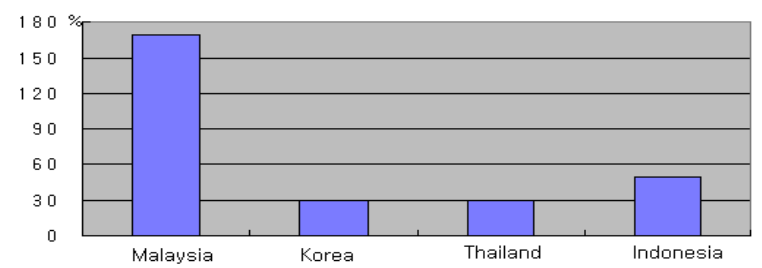

Source: Samsung Economic Research Institute (1999)

There were different economic situations in these countries. Table 1 shows those various measures to overcome the financial crisis.

As shown in Table 1, these measures can be classified as follows ${ }^{[5]}$ :

* IMF with IMF: Korea and Thailand received IMF help and propelled finance and corporate structural reshuffles as requested by the IMF.

* No IMF with IMF: Indonesia received IMF help but didn't accomplish the IMF program because of the local political situation.

* No IMF without IMF: Malaysia refused IMF help and took its own policies that refused opening and liberalizing finance market.

* IMF without IMF: Singapore took liberalized its financial market without the IMF help and tried to prevent the financial crisis.

The measures taken by Korea and Malaysia were different because each country differed in economic structure, types of leaders and various social conditions at the time. Korea targeted to relieve foreign debts and to recover the real economy while Malaysia wanted to strengthen its local industrial competitiveness and to overcome the pressure to open its financial market.

\section{CAPITAL CONTROL POLICY OF MALAYSIA}

Background of capital control policy: The reason that Malaysia took capital control policy was that the economic situation of Malaysia was different from those of other Asian countries. First, it had no problem in foreign currency liquidity. Second, short-term debt ratio was relatively lower than other countries. Third, the problem of local loans was somewhat heavy.

First, Malaysia was in better liquidity condition than Korea or Thailand, as shown in Table 2. The foreign exchange holding of Malaysia was US\$21. 7 billion as of the end of 1997, which was a far greater amount than US\$9 billion of Korea and Thailand. This amount was enough to pay off 3-month imports of Malaysia while Korea can pay only 0.7 -month import and Thailand 1.8 months. The total foreign debts of Malaysia were not so large and maturities of debts were not so pending ${ }^{[6]}$.

Second, The ratio of foreign debts to GDP of Malaysia was $62.7 \%$, which was better than $92.2 \%$ of Thailand though it was somewhat worse than $58.7 \%$ of Korea (Table 2) ${ }^{[7]}$. Malaysia had foreign debts of US $\$ 44.7$ billion (28.5\% of short-term debts) while Korea US\$154. 4 billion (44.3\%), Thailand US\$93. 4 billion (37.3\%), respectively (Table 3 ).

Malaysia's low short-term debt ratio meant that Malaysia had much fewer possibilities for the Financial Crisis. That is, the total foreign debt took $20.4 \%$ of the total annual export amount in comparison with $111 \%$ of Korea and $164 \%$ of Thailand. Malaysia's foreign currency holding was 1.7 times of its short-term foreign debts $^{[8]}$.

Third, Asian countries experienced sharp rises in local loans since the end of 1980 as the economy grows rapidly. In the middle of 1998, the total amount of local loans exceeded the total foreign debts, which eventually led to huge bad debts when the economy went down. Table 4 shows three countries loan loans and capital construction cost (as of the middle of 1998). Each nation NPL (nonprofit loans) ratios were about $25 \%$ in Malaysia and $30 \%$ in Korea and Thailand. Capital construction costs of financial institutions were $22 \%$ of GDP in Malaysia, 30\% in Korea and Thailand ${ }^{[9]}$.

Capital control policy and follow-up measures: As shown above, Malaysia was relatively in a good condition in foreign exchange holding and short-term debts. However, bad loans began to increase. As a result, Malaysia tried to take a somewhat differentiated policy, which was capital control policy. 
Table 4: Local loans and capital construction cost of three Asian countries (unit \%)

\begin{tabular}{llll}
\hline & Malaysia & Korea & Thailand \\
\hline Local Debts (vs. GDP) & 165 & 165 & 155 \\
Real Estate & $30: 40$ & $10: 15$ & $30: 40$ \\
Loans / Mortgage Ratio & $80: 100$ & $60: 100$ & $80: 100$ \\
$\begin{array}{l}\text { Price Increase of Housing } \\
\text { (Vs. A year ago) }\end{array}$ & -16.0 & -2.0 & -20.0 \\
$\begin{array}{l}\text { NPL (Not Profit Loans) } \\
\text { Ratio }\end{array}$ & 25 & 30 & 30 \\
$\begin{array}{l}\text { Capital construction cost } \\
\text { (Vs. GDP) }\end{array}$ & 22 & 30 & 30 \\
\hline Note: Loand & & \\
\hline
\end{tabular}

Note: Loans / Mortgage Ratio are level of 1997

Source: J. P. Morgan

Table 5: Policies implemented by Malaysia, Korea and Thailand

\begin{tabular}{|c|c|}
\hline & \\
\hline Economic & - Local debt problem $\rightarrow$ foreign debt problem \\
\hline Situation & - Credit crisis of foreign exchange market \\
\hline & - Foreign exchange holding was $170 \%$ of short-term debts \\
\hline & - Local loans were $165 \%$ of foreign debts \\
\hline & -High loan ratio to real estates \\
\hline & Korea and Thailand \\
\hline & - Foreign debt problem $\rightarrow$ Local debt problem \\
\hline & - Foreign exchange market credibility and liquidity crisis \\
\hline & - Foreign exchange holding was $30 \%$ of short-term debts \\
\hline & - GDP takes $155-165 \%$ of local loans \\
\hline & Malaysia \\
\hline & - Local economic pump-priming \\
\hline & - Lowering interest rates> Stable exchange rate \\
\hline & Korea and Thailand \\
\hline Policy priorities & Recovering overseas credibility \\
\hline & - Stable foreign exchange rate $>$ Interest rate stability \\
\hline & Malaysia \\
\hline & - Independent policy - Capital control \\
\hline & - Priority on economic boost \\
\hline & - Monetary expansion \\
\hline & - Low interest rate policy \\
\hline & -Delayed \\
\hline Policy & Korea and Thailand \\
\hline & - Recovering overseas credibility \\
\hline & - Stable foreign exchange rate >Interest rate stability \\
\hline
\end{tabular}

Source: Samsung Economic Research Institute (1999)

The situation in the early days of the financial crisis in Asian countries was not so bad, but it worsened in 1998. Consequently, the prime minister recognized that Malaysia needed local economic boosting measures rather than belt-tightening policies of Korea and Thailand $\left[{ }^{10]}\right.$. Malaysia put priorities on pump priming of the economy, although structural reform was one of its goals. Different economic backgrounds of each country had led to different policies. Table 5 shows the differences of economic policies right after Malaysia, Korea and Thailand faced the financial crisis.

On the other hand, Korea puts stress on recovering international credibility. As a result, high interest rates were introduced to stabilize foreign exchange rates and interest rates. Efforts were also made to secure short-term liquidity, foreign debt reduction and structural reform recommended by the IMF.

Table 6 shows the main contents of Malaysias capital control policy ${ }^{[9]}$. First, all money flow among or between foreign accounts should be made after the permission. In addition, all foreign money and money invested in securities of Malaysia had to be retained within Malaysia, which allowed foreign investors to buy Ringgit assets.

Second, in Malaysia residents and non-residents could freely use up to 100,000 Ringgit worth of foreign currency, but they could spend only 10,000 worth of foreign currency per deal except in import or export transactions. Moreover, money withdrawal from external accounts was limited and money couldn't from between those accounts. In trade, Ringgit shouldn't be used so that Ringgit was out of international currency.

Third, as far as overseas investments were concerned, residents who didn't have foreign debts were required to have permission in advance for overseas investments. Regulations on the international balance of payments were re-enforced; Ringgit-based securities had to be transacted through only authorized institutions; Ringgit-based securities should be transacted overseas; and the money garnered from selling securities held less than a year was prohibited from being exchanged for foreign currency. Foreign investment was allowed to move out after one year ${ }^{[11]}$.

These capital control policies were designed to prevent abrupt capital outflow and foreign exchange rate hikes when interest rates were lowered for an economic boost. Malaysian government planned the following: capital control and pegged foreign exchange rate system $\rightarrow$ lowering interest rates $\rightarrow$ loan increase and relieved the burden of debts $\rightarrow$ economic recovery and reduced bad debts $\rightarrow$ credibility recovery among economic participants. As such goals were achieved, Malaysian central banks lowered the open market interest rate (central bank interest rate to commercial banks) to $11 \%$ in August and $8 \%$ in September. The reserve ratio for payments were also lowered to $8 \%$ (end of August) $\rightarrow 4 \%$ (middle of September) and loan margin of banks was forced to go down to $2.5 \%$ from $4 \%$ on September 11.

\section{ECONOMIC ACHIEVEMENT COMPARISON BETWEEN KOREA AND MALAYSIA}

This year, Asian countries which experienced an economic crisis at the end of 1997 are experiencing a distinctive economic recovery, largely thanks to those measures taken after the crisis. Since the end of 1998, foreign exchange market has been stabilized; interest Rates have been lowered; foreign investments have led to stock price increases and economic growth records Korea, Thailand and Philippines recorded plus growth rates during the first quarter and Malaysia recorded $10 \%$ in the 4 th quarter of $1998,-1.3 \%$ at the 1 st quarter of 1999. In particular, Korea and Malaysia changed future economic growth rates to $6.5 \%$ and $4.6 \%$ respectively, showing economic recovery. 
Table 6: Main Contents of Capital Control Policy of Malaysia

\begin{tabular}{|c|c|c|}
\hline Classification & Before & Reform \\
\hline General & $\begin{array}{l}\text { - Free money transfer between foreign account holders } \\
\text { - No limit on money flow of foreign accounts }\end{array}$ & $\begin{array}{l}\text { - Admission required in advance for any money flow between } \\
\text { foreign accounts } \\
\text { - Free money transfer to a resident of foreign accounts up to } \\
\text { September } 30 \text {, but require permission after September } 30 \\
\text { - The overseas account money source is limited to as follows n } \\
\text { Money acquired from selling securities or other assets listed in } \\
\text { Malaysia n Payments, wages, commission, interest, dividend } \\
\text { income n Money acquired from selling foreign currency } \\
\text { - Money can be used to buy Ringget based assets in Malaysia }\end{array}$ \\
\hline $\begin{array}{l}\text { Foreign exchange } \\
\text { regulation }\end{array}$ & $\begin{array}{l}\text { - A Resident can pay up to } 100,000 \text { Ringgit to a } \\
\text { non-resident. More than 100,000 Ringgit } \\
\text { requires other conditions }\end{array}$ & $\begin{array}{l}\text { - A resident can freely pay } 10,000 \text { Ringgit or comparable } \\
\text { foreign currency if it is not for the settlement of trade }\end{array}$ \\
\hline Overseas & $\begin{array}{l}\text { - A resident without local debt can pay to a } \\
\text { nonresident for overseas investment }\end{array}$ & $\begin{array}{l}\text { - A resident without local debt can freely pay } 10,000 \text { Ringgit } \\
\text { or comparable foreign currency to a nonresident for overseas } \\
\text { investment }\end{array}$ \\
\hline Investment & $\begin{array}{l}\text { - A local firm without local debt can invest } \\
\text { less than } 10 \text { million Ringgit a year }\end{array}$ & $\begin{array}{l}\text { - All residents need to have permission for more than } 10,000 \\
\text { Ringgit payments }\end{array}$ \\
\hline $\begin{array}{l}\text { Ringgit loans } \\
\text { from } \\
\text { Non-resident }\end{array}$ & $\begin{array}{l}\text { - A resident can borrow less than } 100,000 \\
\text { Ringgit from a non-resident }\end{array}$ & - No loan from a non-resident to a resident allowed \\
\hline \multirow[t]{2}{*}{ Securities } & $\begin{array}{l}\text { - No regulation in transacting securities listed in Malaysia } \\
\text { among residents and non-residents } \\
\text { - A resident can buy overseas securities from a non-resident } \\
\text { under overseas investment regulation of Malaysia }\end{array}$ & $\begin{array}{l}\text { - Ringgit securities should be entrusted to an } \\
\text { authorized institution } \\
\text { - Nonresidents securities should be transacted through } \\
\text { authorized institutions } \\
\text { - Nonresidents can use foreign currency or Ringgit at } \\
\text { overseas account }\end{array}$ \\
\hline & & $\begin{array}{l}\text { - Money earned from selling Malaysian securities can be kept } \\
\text { at overseas accounts When Ringgit securities are held more } \\
\text { than a year and Proceeds from the sale can be exchanged for } \\
\text { foreign currency or deposited to overseas accounts n A } \\
\text { resident should get paid with foreign currency when overseas } \\
\text { securities are sold }\end{array}$ \\
\hline
\end{tabular}

Source: Adapted from information provided by the Central Bank of Malaysia

Table 7: Quarterly economic growth rates of East Asian countries

\begin{tabular}{llllll}
\hline (Unit: $\%)$ & $98.1 / 4$ & $2 / 4$ & $3 / 4$ & $4 / 4$ & \\
\hline Korea & -3.6 & -7.2 & -6.3 & -6.6 & $99.1 / 4$ \\
Philippines & 1.2 & -0.8 & -0.7 & -1.9 & 1.6 \\
Thailand & -8.0 & -12.3 & -12.5 & -5.0 & 0 \\
Malaysia & -3.1 & -5.2 & -10.9 & -10.3 & 0.9 \\
Indonesia & -4.0 & -12.3 & -18.4 & -19.5 & -1.3 \\
\hline
\end{tabular}

Source: Statistic of the Central Bank of each country

Table 8: Korean economic and financial trend after IMF financial support

\begin{tabular}{lllll}
\hline & 97.12 & 98.6 & 98.12 & 99.6 \\
\hline $\begin{array}{l}\text { Foreign exchange } \\
\text { holding / Short-term } \\
\text { debts(times) }\end{array}$ & 0.31 & 0.96 & 1.22 & $\begin{array}{l}1.89 \\
\text { (End of March) }\end{array}$ \\
$\begin{array}{l}\text { Dollar / Won } \\
\begin{array}{l}\text { Call interest rate } \\
\text { (yearly \%) }\end{array}\end{array} \quad 1,695$ & 1,370 & 1,200 & 1,157 \\
Stock price index & 35.0 & 14.3 & 6.8 & 4.8 \\
\hline
\end{tabular}

Note: as of end of a month

Economic and financial statistics during the overcome of the Financial Crisis shows the following: First, Korea achieved financial market stability, foreign exchange market and real economic recovery since the middle of 1998. Foreign exchange liquidity has been improved a lot through the foreign exchange holding increase, redemption of short-term debts (the ratio between short-term debts/ foreign exchange holding: $0.31(97.12) \rightarrow 1.89(99.3)$ ). Foreign exchange rate has shown downturn stability since early 1998 and the call rate went down to current $4 \%$ from $35 \%$ in 1997 . The stock market experienced its first rise at the end of 1998 and another rise in May 1999 to current 883 (Korea Composite Stock Price Index) in June 1999 (Table 8).

On the other hand, the operation ratio of the manufacturing sector increased by 22.4\% in May 1999 from the year ago and recorded around 60\% in 1998 and $76.5 \%$ in May 1999. Exports increased to US\$13 billion for the half of 1999, $12.8 \%$ increase from the year ago. It was the highest export amount ever recorded. As a result, consumption also increased $13.1 \%$ during the first quarter of 1999 and $17.7 \%$ in May the same year (Table 9).

Second, economic achievement was shown from the export sector in Malaysia, largely due to stabilized the foreign exchange market and exchange rate, which was the result of the strong capital control policy of the government and low interest rate policy of the central bank. Malaysia's unique feature was: pegged foreign exchange rate (US\$3. 8), which minimize the bad side of extreme depreciation; low interest rate up to $2.5 \%$ in June 1999 (Table 10). 
Am. J. Applied Sci., 2 (9): 1315-1320, 2005

Table 9: Production and exports increase of Korean manufacturing industry

\begin{tabular}{|c|c|c|c|c|c|c|c|}
\hline & 98.12 & 99.1 & 99.2 & 99.3 & 99.4 & 99.5 & 99.6 \\
\hline $\begin{array}{l}\text { Production of } \\
\text { manufacturing sector }(\%)\end{array}$ & 5.1 & 15.0 & 3.9 & 19.4 & 17.5 & 22.4 & - \\
\hline Export $(\%)$ & -0.1 & 3.0 & -16.8 & -2.5 & -4.1 & 1.9 & 12.8 \\
\hline
\end{tabular}

Table 10: Economic and financial status of Malaysia after foreign exchange crisis

\begin{tabular}{|c|c|c|c|c|}
\hline & 97.12 & 98.6 & 98.12 & 99.6 \\
\hline Foreign exchange holding /Short-term debts (times) & 1.24 & 1.60 & 3.01 & 3.83 (End of March) \\
\hline Ringgit / US Dollar & 3.88 & 4.12 & 3.8 & 3.8 \\
\hline Call interest rate (yearly \%) & 8.79 & 10.31 & 5.14 & 3.48 \\
\hline Stock price index & 594 & 456 & 586 & 811 \\
\hline
\end{tabular}

Table 11: Production and export increase of Malaysia

\begin{tabular}{llllll}
\hline & 98.12 & 99.1 & 99.2 & 99.3 & 99.4 \\
\hline Production of manufacturers (\%) & -13.7 & -17.1 & 4.9 & 4.3 & 4.5 \\
Exports $(\%)$ & 12.3 & 12.0 & -1.5 & 4.3 & 14.3 \\
\hline
\end{tabular}

Table 12: Economic achievement comparison between Korea and Malaysia

\begin{tabular}{lll} 
& Korea & Malaysia \\
\hline Economic growth rate (\%; first quarter 1999) & 4.6 & -1.3 \\
Stock price increase (\%; first half 1999) & 57.0 & 38.4 \\
Production increase of manufacturing (\%) & 22.5 (May) & 4.5 (April) \\
Export increase ratios (\%) & 12.8 (June) & 14.9 (May) \\
Direct foreign investment & 44.6 Billion Dollars (81.4 \% Increase) & 5 Billion Dollars (-63 \%) \\
\hline
\end{tabular}

Note: Direct foreign investment is during the first half in Korea and up to end of April in Malaysia

From March 1999, exports of petroleum, gas and electronic products showed good signs. The production of the manufacturing sector showed a three-month consecutive increase since February 1999. Further, consumption rapidly recovers for brighter economic prospects. Imports of consumer products increased 17.2\% in April and sales tax increased 45.8\%.

Comparing overall economic accomplishments of both countries, both countries are considered very positive. In economic growth rates, Korea showed better figures; Korea recorded $4.6 \%$ for the first quarter of 1999 , more than $6 \%$ expected in 1999 and $-3.8 \%$ for the first quarter of 1998 while Malaysia recorded 1.3\%, $2 \%,-3.1 \%$ respectively. The Korean stock market also showed better figures and direct investment, which represents overseas credibility, show good figures in Korea $^{[8,9]}$.

However, Korea and Malaysia responded to the crises with different approaches. Therefore it is very hard to judge which approach or policy is superior. Refer economic accomplishments in Table 12.

\section{CONCLUSION}

Swept by the unavoidable international market force, East Asian countries experienced a severe foreign exchange crisis. Korea and Malaysia, however, took different ways to overcome the crisis. Korea relied on IMF support, which, of course, became a great help for economic recovery and accomplishments, while Malaysia pursued its own countermeasures such as a strong capital control policy and achieved economic recovery.

The most common reasons for the foreign exchange crisis include regionalism frequently observed all over the world, vulnerable financial markets and inefficient corporate structures. As the capital market has been liberalized, most developing countries, which showed instability in their financial markets and did not have enough time to properly proceed corporate structural reform, have experienced foreign exchange crisis.

After careful analysis, this study concluded that although the countermeasures Korea and Malaysia took to overcome the crisis were different, their results were similar. This study will focus on comparing the background which made two countries implement different economic policies and the results of such policies; the IMF-leading policies of Korea and the independent recovery programs of Malaysia resulted in almost equal economic achievements. Korea has taken steps to be passively absorbed by a new trend of the world economy while Malaysia has implemented its own economic policies ignoring such trend.

In conclusion, in order to draw the best economic policies, it seems important to gain an insight into the flow of the world economy and to take advantage of it depending on the economic circumstances of each country. The capital control policy taken by the Mahathir administration was a relatively reasonable choice that led to two-digit economic growth rate and Korea should get the lessons that such independent policies imply.

There is no better, absolute policy in an ever-changing international economy. Through the processes by which they have overcome foreign exchange crises, Korea and Malaysia show how important it is that a country cooperates with others in 
an interdependent economic system while fostering the foundation of an independent economy.

\section{REFERENCES}

1. Park, Won-am Fal., 2001. Was Korea's Financial Crisis Self-fulfilling? The J. Korean Econ., 1: 301-323.

2. Yang, Doo-Yang, 2002. Economic reform in post crisis Korea. The J. East Asian Affairs. The Research Institute for International Affairs, 16: 255-281.

3. Joon-Kyung Kim and C.H. Lee, 2002. Insolvency in the corporate sector and financial crisis in Korea. J. Asia Pacific Econ., 7: 267-281.

4. Lee, Dong-Choon, 2001. The political impact of the 1997 financial crisis in Malaysia: Impetus for political reform. Mokpo Sci. Rev., Mokpo Sci. Coll., 25: 419-451.

5. Samsung Economic Research Institute, 1997. IMF and Economic Structural Reform, pp: 1-30.
6. ABN-AMRO, 1999. Asian Market Quarterly. Jan.-Mar., 1999: 39-64.

7. Park, Beun-soon and Kim, Jong-Nyun, 1999. Comparison between Korea and Malaysia, CEO Information. Samsung Economic Research Institute, pp: 1-14.

8. Park, Beum-Soon, 1998. Malaysian economy in the midst of foreign exchange crisis in Southeast Asia. Samsung Economic Research Institute, 68: 1-25.

9. Lee, Jaymin, 2001. Korean Financial Crisis: The Crisis of a Development Model? Tzong-shan Yu and Dianqing Xu (Eds.), From Crisis to Recovery: East Asia Rising Again? World Scientific, pp: 101-140.

10. Malaysian Industrial Development Authority, 1999. Malaysia-Investment in the Manufacturing Sector-Policies. Incentives and Facilities, Kuala Lumpur, pp: 1-326.

11. Park, Beun-Soon, 1999. Effects of Capital Control Policy in Malaysia, Issue Paper, Samsung Economic Research Institute, pp: 1-38. 